Brit. F. industr. Med., 1966, 23, 292

\title{
Acute Cadmium Fume Poisoning Five Cases with one Death from Renal Necrosis
}

\author{
D. C. BETON, G. S. ANDREWS, H. J. DAVIES, LEONARD HOWELLS, and G. F. SMITH \\ From Cardiff Royal Infirmary, Royal Gwent Hospital, Newport, \\ and H.M. Medical Inspectorate of Factories
}

This paper describes the accidental poisoning of five workers by cadmium fume. The men were dismantling a frame of girders in a confined space by cutting bolts with an oxyacetylene burner. They were unaware at the time that the bolts were cadmium-plated or that this presented a serious industrial hazard.

The paper sets out to give an appreciation of acute cadmium poisoning, the characteristics and uses of cadmium, and a review of the literature. The clinical picture of these cases is described, with the pathology of the fatal case which showed severe pulmonary oedema, alveolar metaplasia of the lung, and bilateral cortical necrosis of the kidneys. The lungs contained $0.25 \mathrm{~g}$. cadmium oxide (CdO) per $100 \mathrm{~g}$. wet specimen.

An attempted estimation of the fatal dose of $\mathrm{CdO}$ fume is made. From the post-mortem findings, using an assumption that $11 \%$ of inhaled $\mathrm{CdO}$ will be retained in the lungs, approximately $51.7 \mathrm{mg}$. CdO fume must have been inhaled by the fatal case. As he worked for five hours with a probable ventilatory rate of 201 . $/ \mathrm{min}$. the concentration of $\mathrm{CdO}$ in the air breathed would be of the order of $8.6 \mathrm{mg} . / \mathrm{m} .{ }^{3}$. An estimation of the dose from a study of the working conditions proved unsatisfactory due to certain variables listed in the text.

Cadmium is a useful metal obtained as a byproduct of zinc smelting. It occurs naturally as cadmium sulphide (Greenockite). It polishes well and resists corrosion especially by alkalis and salt water. This property and its being anodic to ferrous metals make it a valuable rust preventive when electroplated on iron and steel. This is its main use, especially in marine situations for protecting ships' gear, in humid tropical conditions, and in wet and alkaline industrial places such as laundries. It makes useful alloys with copper, silver, and other metals, which, because of high electrical conductivity, find widespread use in the electrical industry and also as brazing strip. It is used in the photographic, rubber, motor, and aircraft industries. It is used for accumulator plates, and the sulphide in pigment is used for paint and glass. In nuclear reactors the control rods may be made from cadmium steel alloys. In 1956 the world production exceeded 8,500 tons (Lamy, Heully, Pernot, Anthoine, Couillant, and Thomas, 1963) and this is rapidly increasing.

The metal melts at $320^{\circ} \mathrm{C}$. and boils at $767^{\circ} \mathrm{C}$., but when heated in air it readily oxidizes and may ignite, producing yellowish-brown cadmium fume

Received for publication December 1, 1965. which tends to settle as fine dust on nearby cold objects.

Cadmium salt is toxic by mouth, producing marked gastro-intestinal upset, but the oxide by inhalation is at least 60 times as toxic (Macfarland, 1960). This toxicity has been recognized for over Ioo years since Sovet (1858) described illness from inhaled silver polish (cadmium carbonate). Most early studies were of oral toxicity, but a few cases of poisoning by inhalation were described (Stephens, 1920). The great importance of inhalation was stressed by Prodan (1932) who summarized and clarified the knowledge of acute poisoning and showed by animal experiments the direct effect of cadmium on the lungs, its general toxic action, its effect on the central nervous system, and its tendency to be stored in liver and kidney with slow elimination from the body.

There have subsequently been many reports of acute poisoning by inhalation due to a variety of causes, but all have involved the heating of cadmium metal or alloy. An annealing furnace charged with cadmium-plated rivets produced fumes which poisoned 14 men, two of whom died (Bulmer, Rothwell and Frankish, 1938). This accident was later reconstructed and studied by Barrett, Irwin, 
and Semmons (1947). A factory fire in a cadmium recovery plant was caused by the ignition of cadmium dust by a cigarette (Shiels and Robertson, 1946). Twenty-three people were affected, particularly the firemen fighting the fire. Five cases due to heating cadmium-plated pipe were reported by Spolyar, Keppler, and Porter, (1944). Many victims have been welders, unsuspectingly cutting or welding plated, coated or alloyed metal (Christensen and Olsen, 1957; Evans, 1960; Lamy et al., 1963). A cadmium spraying machine for coating steel was allowed to overheat and filled the plant with fumes, affecting 17 men (Reinl, 196I). The clinical picture of acute poisoning was fully described in many of these reports (Table I) and the pathology was added (Paterson, 1947; Christensen and Olsen, 1957).

TABLE I

Clinical Features

Main Symptoms Reported in Literature

No. of Our Patients with These Symptoms

During exposure (latent period o-4 hours)

Slight irritation of throat and mucosae

Stage of irritation (like starting influenza 4-10

hours)

Irritation of throat with feeling of constriction Cough

Tight chest

Pain in chest on coughing

Dyspnoea

Malaise, 'ague', chill

Sweating

Shivering

Aching pains in back and limbs

Headaches and dizziness

Metallic taste in mouth

Irritation and soreness after smoking

Stage of pulmonary reaction ( 8 hours to 7 days)

Severe dyspnoea and wheezing

Chest pain and precordial constriction

Persistent cough

Weakness and malaise

Anorexia, nausea, and perhaps diarrhoea and nocturia

Abdominal pain after meals

Haemoptysis

Prostration

Fairhall (1947) pointed out that most cases were of unsuspected origin and stressed the danger of heating coated or alloyed metal. He suggested labelling cadmium-containing metals as a warning, and found 59 cases in the literature with $15 \%$ mortality. In I960 Smith, Smith, and McCall found over 90 cases with 15 deaths.
Though there were reports of cumulative effects of cadmium as early as 1920 (Stephens), little was known of chronic poisoning until the classical description by Friberg (I950) of an insidious progressive disorder appearing after several years' exposure to cadmium. There is emphysema with relative absence of chronic bronchitis, anosmia, proteinuria, and a renal tubular dysfunction similar to the Fanconi syndrome. The protein is not specific to this disease and has a low average molecular weight $(30,000)$; the presence of globulin indicates a 'tubular' origin (Kazantzis, Flynn, Spowage, and Trott, 1963).

Long-term effects of a single acute exposure to cadmium fumes have not been described. Huck (1947) stated that between 1858 and 1945 there were 64 reported cases in the literature, of whom Io died, mainly about the seventh day after exposure. He added, quoting Johnstone (I94I), that there was then no reason to believe that a permanent disability results. However, he also pointed out the difficulty of detecting cadmium in the tissues and the absence of laboratory tests to aid diagnosis, and it is not clear how effectively these cases were followed up.

\section{History of Episode}

The team of five male workers was employed inside the top of a tower to dismantle a frame of girders. One man was a burner and four were steel erectors. Cadmium-plated nuts, bolts, and washers had been used to construct the frame and, in the circumstances of the work, it was decided to break down the frame by melting away these steel bolts with an oxyacetylene burner. By doing so, cadmium oxide was given off in quantities sufficient to produce acute cadmium poisoning, a diagnosis confirmed by the post-mortem findings in case $\mathbf{I}$.

Dismantling took five hours. The working space was enclosed and had neither natural nor induced ventilation. The men did not wear dust respirators except that the oxyacetylene burner wore his usual mask protection.

Nothing in the exposure gave the men reason to suspect the seriousness of inhaling cadmium oxide fume. The firm was unaware of the toxic risk of burning cadmium: in the fatal case, the general practitioner was told by the patient that he had been exposed to carbon dioxide. The death was reported to H.M. coroner.

On learning about the fatal case, the firm employing the men made enquiries through H.M. District Inspector of Factories and, when informed that cadmium oxide fume was toxic, they enlisted the 
help of the Medical Officer of Health in whose area the other four workers lived; each man was successfully persuaded to enter hospital at once.

\section{Case Reports}

Case I T.E.B., aged 53, was a steel erector, whose health had been good apart from some eczema.

He was present throughout the operation of burning the bolts and afterwards for the period of five hours that the men were exposed. His symptoms began that daymainly an irritating cough, breathlessness, and feeling unwell. He was able to go to work the next day when he found that his mates had the same symptoms, but during the next two days he seemed to be getting much worse than them, a fact which he attributed to his age. On the third day he called his doctor who found him in bed breathless, cyanosed, and with a pyrexia of $10{ }^{\circ} \mathrm{F}$., pulse $98 / \mathrm{min}$., blood pressure $160 / 90 \mathrm{~mm}$. $/ \mathrm{Hg}$, and signs in the chest of reduced breath sounds at the bases. His doctor thought he looked much worse than the clinical signs suggested and treated him for bronchopneumonia. Neither patient nor doctor knew he had been exposed to cadmium, though it was thought that he had been exposed to carbon dioxide. His condition was unchanged throughout the next day, but on the fifth day there appeared to be a slight improvement in the chest. The temperature was normal, and cyanosis was less, but he had haemoptysis. By the afternoon of the fifth day his condition had again deteriorated and he died soon afterwards. The case was reported to the Coroner's Officer because of the suspected 'gassing incident' with carbon dioxide. Cadmium poisoning was suspected by the pathologist, and the contractors were notified. With the help of the Factory Inspectorate the four other men were then traced and admitted to hospital.

Case 2 I.B. aged 42, a welder, had previously had good health except for a duodenal ulcer. He is a pipe smoker. He operated the burner to cut the cadmiumplated bolts. During the operation he became aware of an unpleasant taste in the mouth and a feeling of hotness and coldness, but he did not feel ill for several hours. He then developed tightness and soreness of the middle of the chest and a feeling of a lump in the abdomen. He and his mates felt ill before the end of the shift but managed to finish it. He then went straight home to bed, with a tight chest; short, shallow, difficult respirations, a dry cough, anorexia, and insomnia. After a restless night due to dyspnoea, he was able to go to work but did a lighter job, avoiding confined spaces. For three nights he was thus restless, breathless, and sleeping poorly and during the day dyspnoeic on exertion, with a hard, dry cough. The fourth night he slept well and the fifth day he felt much better. On the sixth day he had haemoptysis. Later that day, on admission to hospital, he was found to be well but had noticeable effort dyspnoea. His blood pressure was $170 / 100 \mathrm{~mm}$. Hg. No other significant signs were evident.

His Hb was $105 \%$, white cell count 6,900 per mm. ${ }^{3}$, E.S.R. $19 \mathrm{~mm}$./hour on admission but $6 \mathrm{~mm}$./hour one week later; blood urea $32 \mathrm{mg}$./100 ml., total serum protein $7.1 \mathrm{~g} . / 100 \mathrm{ml}$., albumin $4.0 \mathrm{~g} . / 100 \mathrm{ml}$. Alkaline phosphatase was 8.2 King Armstrong units and thymol turbidity I. There was a raised concentration of seromucoid and total protein-bound carbohydrate in the serum. The lung function tests are shown in Table II. From the sputum Haemophilus influenzae and Diplococcus pneumoniae were cultured. Urine: S.G. I,000 to 1,013 maximum, normal deposit, no albumin. No cadmium was found in the urine. An E.C.G. showed left axis deviation, $T$ wave inversion in $S_{3}$, and flat $T$ in aVf.

TABLE II

Lung Function Tests

(by method of Gaensler 1951)

\begin{tabular}{l} 
Date \\
\hline $\begin{array}{l}\text { Admission } \\
\text { 2.10.1963 }\end{array}$ \\
17.2.1964
\end{tabular}

\begin{tabular}{cclcr}
\hline Case 2 & & & & \\
Height & $168 \mathrm{~cm}$. & F.E.V.1.0 $(l)$. & 3.45 & 3.85 \\
& & V.C. $(l)$. & $4 \cdot 2$ & $4 \cdot 40$ \\
Weight & $80 \cdot 1 \mathrm{~kg}$. & M.B.C. $(l)$. & 120 & 134
\end{tabular}

Case 3

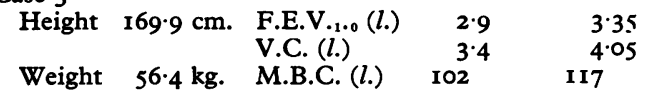

Case 4

$\begin{array}{rrlrr}\text { Height } & 176 \cdot 3 \mathrm{~cm} . & \text { F.E.V.1.0 }(l .) & 4 \cdot 0 & 4 \cdot 1 \\ & & \text { V.C. }(l .) & 4 \cdot 0 & 5 \cdot 6 \\ \text { Weight } & 71 \cdot 4 \mathrm{~kg} . & \text { M.B.C. }(l .) & 140 & 143\end{array}$

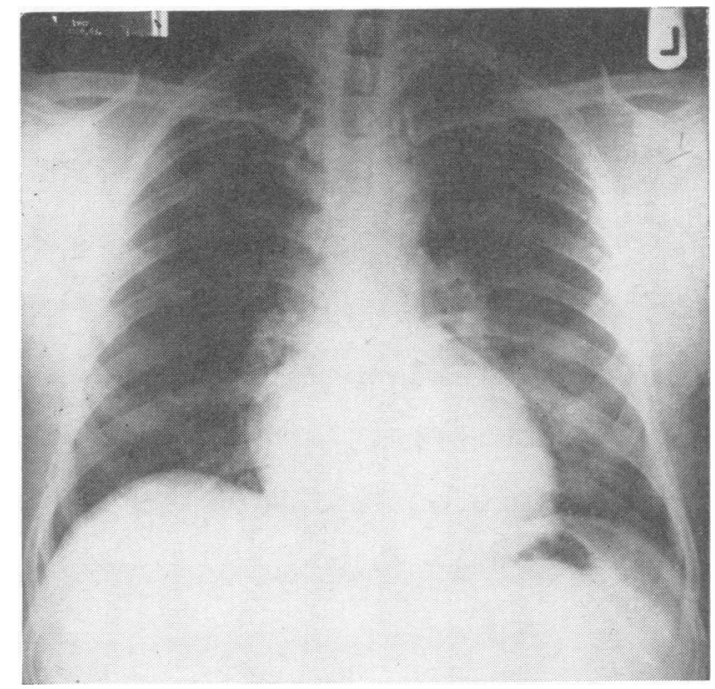

FIG. I. Case 2. Chest radiograph showing appearances of pulmonary oedema seven days after exposure. 
There were plane ST segments with low amplitude (0.5 $\mathrm{mm}$.) biphasic $\mathrm{T}$ waves in $\mathrm{V}_{2}$ to $\mathrm{V}_{4}$.

The chest radiograph showed ill-defined, homogeneous shadowing in the left mid-zone which may be due to pulmonary oedema (Fig. I). The remainder of the lung field was clear and the heart shadow was normal. The changes were slow in resolving but were mainly clear 19 days after the exposure.

Case 3 F.G.S. aged 38, a steel erector, had previously been in good health but had smoked 30 cigarettes a day for years.

He first noticed symptoms two to three hours after starting the job, with loss of appetite and sweating. A few hours later he had developed shivering, sweating, and an aching pain in the back, arms, and legs, the limbs feeling 'like lead'. Difficulty was experienced with breathing and he retired to bed early but did not sleep. He had complete anorexia, profuse sweating, and loose bowels initially, though later he developed constipation. Next day he stayed at home though he was able to work on subsequent days. His symptoms continued, mainly sweating and dyspnoea at night.

On admission to hospital on the sixth day he was fairly well. A faint cyanosis was present and evident effort dyspnoea but no other physical signs.

His $\mathrm{Hb}$ was $92 \%$, W.C.C. 7,800 per mm. ${ }^{3}$, neutrophils $64 \%$, lymphocytes $32 \%$, monocytes $4 \%$. The E.S.R. was $39 \mathrm{~mm}$./hour on admission but fell to 8 $\mathrm{mm}$./hour Io days later. Urine: S.G. I,000 to $\mathrm{I}, 018$

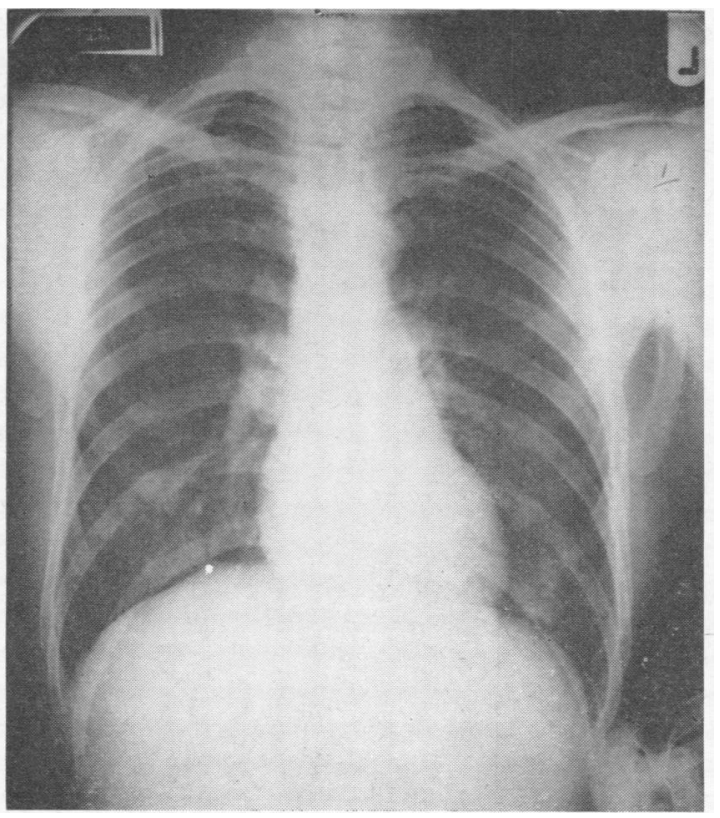

FIG. 2. Case 3. Chest radiograph showing less marked changes-seven days after exposure. maximum; urine deposit contained a few red blood cells and very scanty pus and epithelial cells. From the sputum haemolytic streptococci and D. pneumoniae were grown. Blood urea was $32 \mathrm{mg}$./100 ml. Total serum protein was $5.9 \mathrm{~g}$. $/ 100 \mathrm{ml}$. with albumin 3.6 g./100 ml. Alkaline phosphatase was 9.6 King Armstrong units and thymol turbidity 2 units. The concentration of seromucoid and total protein-bound carbohydrate was raised. Serum protein electrophoresis was normal except for rather low albumin. A 24-hour urine collection contained $4 \mathrm{mg}$./ $100 \mathrm{ml}$. protein which was shown by electrophoresis and immunoelectrophoresis to consist almost entirely of albumin. The E.C.G. was normal. Chest radiographs showed patchy, ill-defined shadowing in the left mid and lower zones and right base. The vessels in these areas are crowded together, suggesting areas of pulmonary collapse (Fig. 2). Subsequent radiographs, two weeks after the exposure, were practically normal.

Case 4 R.M.D. aged 35, a steel erector, had had good health except for a hernia operation and a chronically discharging ear. He smokes 20 cigarettes a day.

During exposure to the fumes he developed irritation of the throat followed by a burning sensation in the chest, discomfort in the back, and a muzzy head. About four to six hours later he had become very weak with a cramp-like pain at the knees and sweating. He finished the shift, but when he reached home he was cold and shaking. He went to bed early and had profuse sweating though he slept fairly well. Next day, in spite of feeling unwell with pain in the knees, tight chest, weakness and sweating, he went to work. For the next three days he had malaise, a tight chest, sweating, weakness, considerable effort dyspnoea and anorexia, and a muzzy feeling in the head. He found that smoking caused severe burning in the chest. On admission to hospital on the sixth day he was quite well with no clinical abnormalities in the respiratory or any other system except for a discharging right ear.

His $\mathrm{Hb}$ was $115 \%$, W.C.C. $13,300 / \mathrm{mm}{ }^{3}$, E.S.R. 8 $\mathrm{mm}$./hour. The blood film and differential count were normal. Blood urea was $32 \mathrm{mg}$./100 ml. Total serum protein was $7.4 \mathrm{~g}$. $/ 100 \mathrm{ml}$; albumin $4.2 \mathrm{~g} . / 100 \mathrm{ml}$. Alkaline phosphatase was $10 \cdot 2$ King Armstrong units per $100 \mathrm{ml}$. and thymol turbidity was 3 units. In serum a raised concentration of seromucoid and total proteinbound carbohydrate was detected. Urine: S.G. I,000 to I,020 maximum. There was frank haematuria on the day of admission, and next day, but one week later the deposit was normal. Traces of proteinuria were detected on only the first two days. From the sputum H. influenzae and haemolytic streptococci were grown. The E.C.G. was normal. Chest radiographs showed changes similar to those of cases 2 and 3 but much less marked; without knowledge of the clinical picture these could be passed as normal. job.

He remained very well and returned later to his former

Case 5 T.J.L. aged 39, a steel erector, had been in good health except for a recent attack of orchitis. 
Six days after the exposure to cadmium he was admitted under the care of Dr. Grahame Jones to the Royal Gwent Hospital. His main initial symptoms were shivering, general malaise, aches and pains, and sweating, followed next day by shortness of breath on exertion, wheezing, and chest pain on deep respiration which caused him to cough. The cough was non-productive and there was no haemoptysis. His appetite was good but he vomited the night before his admission. Abdominal pain after meals occurred though he did not usually suffer from indigestion. He had 'looked off colour' for a few days but there had been no jaundice. The bowels were normal. Nocturesis occurred in the first week but no dysuria or haematuria. Pain in the limbs, mainly in the calves, and also 'pins and needles' in the left foot were noted. He had been sleeping well. On admission he was observed to be clinically well, and full examination showed no abnormal signs.

His $\mathrm{Hb}$ was $94 \%$, W.C.C. I0,300/mm. ${ }^{3}$, E.S.R. Io $\mathrm{mm}$./hour. Liver function tests were normal. Serum electrolytes were normal. Blood urea was $34 \mathrm{mg}$./ Ioo ml. Four days after admission the $\mathrm{Hb}$ was $103 \%$, W.C.C. $9,400 / \mathrm{mm}^{3}$, and E.S.R. $6 \mathrm{~mm}$./hour. The blood urea was $28 \mathrm{mg}$./ $/ 00 \mathrm{ml}$. The urea clearance test was normal. The urine showed no significant changes and the sputum cultured normal bacterial flora. An E.C.G. showed no abnormal changes and the chest radiograph showed no evidence of a lung lesion.

Subsequently, he remained very well, went home after eight days in hospital, and resumed work in a few weeks.

\section{Pathology}

The necropsy on case I (aged 53) was carried out by one of us (G.S.A.) 72 hours after death and showed a well nourished man, $5 \mathrm{ft}$. IO in. ( $1 \cdot 78 \mathrm{~m}$.) tall with a striking degree of cyanosis. The principal findings were confined to the respiratory tract and kidneys, most other organs being normal. There were, however, small pleural effusions. There was moderate coronary artery atheroma and atheroma of the aorta and other arteries consistent with his age. The heart, weighing $387 \mathrm{~g}$. was otherwise normal. The spleen was firm and showed some simple congestion but the liver and alimentary tract were normal.

The mouth, pharynx, and larynx were normal but the trachea and bronchi were intensely hyperaemic and bright pink in colour, containing a large amount of frothy, dirty, brown fluid. Both lungs were heavy; the right weighed 1,205 g. and the left I,078 g.; they were firm to the touch externally. There was massive pulmonary oedema. The cut surfaces were a dirty grey colour and from them a large amount of fluid flowed. The lung substance appeared to be degenerate, as if infected, but it was quite solid to the touch.

The kidneys were swollen and the cut surfaces bulged. The cortex and medulla were of normal size and fairly clearly demarcated but just outside the junctions between the two there was a yellow zone of necrosis. This was present in all areas of the kidneys and the appearances were quite typical of cortical necrosis. The glomeruli were prominent and dark red in colour. Only about $3 \mathrm{ml}$. urine was found in the bladder.

A large lung section showed contrast between the dark central areas and a pale rim beneath the pleura which showed acute emphysema. Consolidation was present in the central part but was not complete, some of the air spaces being empty.

Histology of the lungs (Fig. 3) showed extreme congestion with large areas of intra-alveolar haemorrhages which were associated with thrombi in the pulmonary arteries. In the alveoli were large numbers of macrophages carrying iron pigment, some oedema fluid, and a fibrinous intra-alveolar exudate. The majority of alveoli were lined by large cells giving a striking and characteristic beaded appearance. In haematoxylin-eosin preparations these cells had a deep reddish-purple cytoplasm. There was usually a single darkly staining nucleus and a prominent chromatin network. Metaplasia of the alveolar lining cells was present and, over large areas, the alveoli were full of large cells which had the same appearance as those lining the alveoli. In addition some of these cells were of giant form and multinucleate. These intra-alveolar cells were probably shed from the alveolar lining. Though it is possible that this could have occurred after death, the concentration of cells was so great and appearances were such as to suggest that this filling occurred during life. The bronchial lining epithelium had also been shed in some areas, so that it was difficult to establish any connexion between the lining of the bronchi and alveoli.

Histology of the kidneys (Figs. 4 and 5) was quite typical of bilateral cortical necrosis and this was more extensive than was suggested microscopically. Almost all the cortex was involved and nearly every glomerulus showed partial or complete infarction with thrombi occluding the lumen of the capillary tuft. Thrombotic occlusion of the intralobular arteries and afferent arterioles was frequently seen. There was no acute necrosis of blood vessel walls and there was no generalized acute inflammatory reaction. The tubules showed widespread damage with various stages of degeneration, sometimes amounting to complete loss of nuclei, but the tubular disintegration was not complete. These changes were maximal in the mid-zone of the cortex. A small number of protein and granular casts was present in the tubules but no pigment casts were seen. Some of the collecting tubule cells contained small 


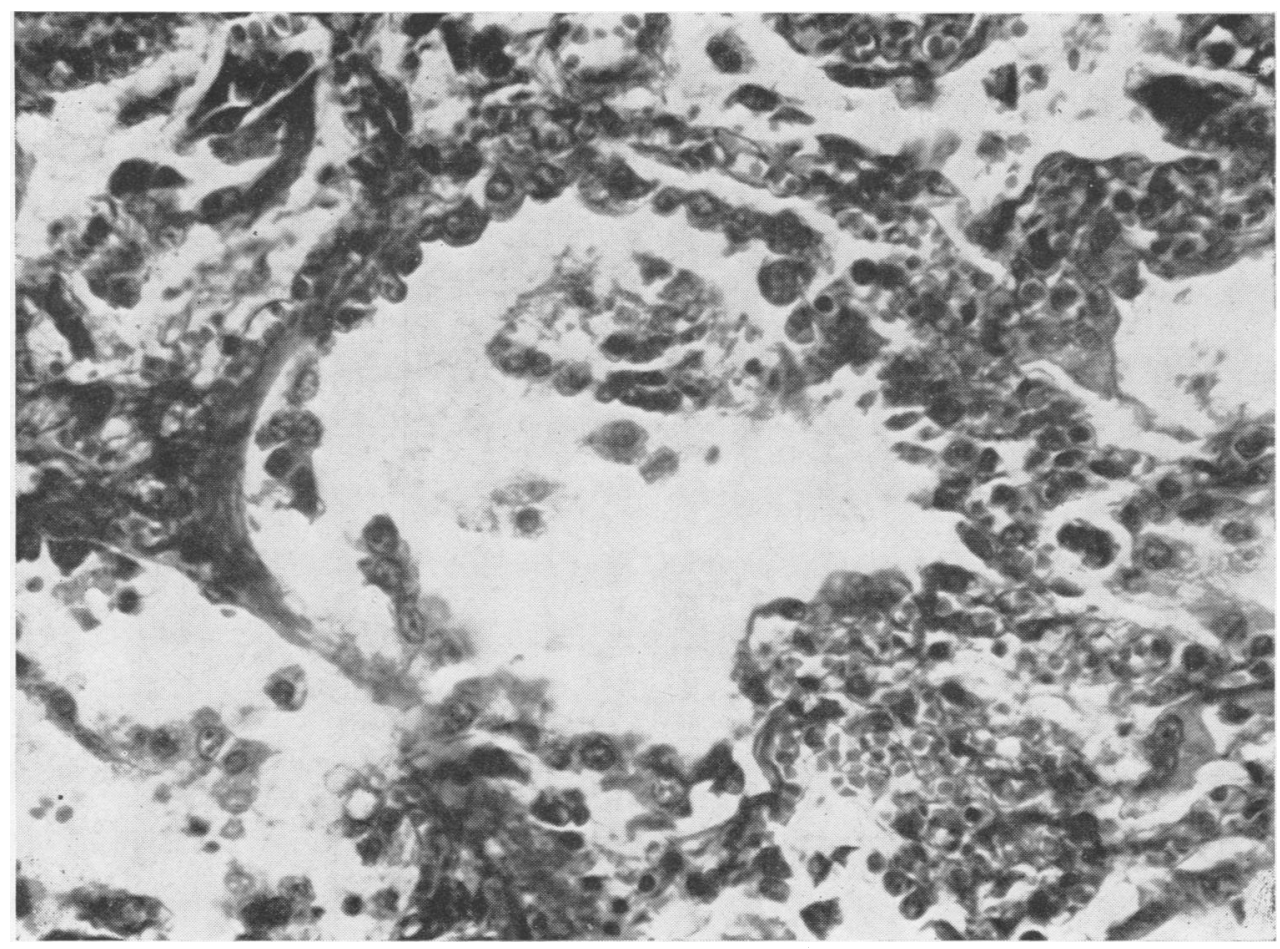

FIG. 3. Histology of lungs showing alveolar metaplasia. $\times 375$.

particles of brown pigment which could not be identified and which did not give the staining reaction for iron.

Histology of the liver and testis was normal and the spleen showed simple congestion with arterioscelerosis.

An analysis of organs for cadmium oxide showed the following concentrations per $100 \mathrm{~g}$. wet specimen: kidneys $0.57 \mathrm{mg}$; ; liver $0.32 \mathrm{mg}$; and lungs $0.25 \mathrm{mg}$.

No cadmium was found in the stomach contents, blood, urine, brain or spleen.

\section{Lethal Dose of Cadmium Fume in Acute Poisoning in Humans}

Christensen and Olsen (1957) stated that 'cadmium has probably more lethal possibilities than any of the other metals' quoted by Ethel Browning (I96I). Drill (I954) claimed that 'concentrations of I mg./cu. metre can cause death'. Nevertheless the measurement of dosage of cadmium fume in acute poisoning cases is sparsely documented in the literature.

Ethel Browning (196I) directs attention to the studies of Canadian workers. Barrett and Card (1947), and Barrett et al. (1947) determined the acute toxicity of cadmium fumes both from the results of animal experiments and from the postmortem findings in two fatal cases first reported by Bulmer et al. (1938). Barrett and Card (1947) reproduced the working conditions in the factory concerned, and from their results of animal reaction and atmospheric contamination they reported the 'lethal dose of thermally generated cadmium oxide for a man doing light work is not over 2,900 minutemg./cu. metre'.

Barrett et al. (1947) used the forensic method of estimating the fatal 'dose' in minute-mg. $/ \mathrm{m}^{3}{ }^{3}$ from the amount of cadmium oxide found lungborne at necropsy. Other factors needed for their calculations were an assumption of the respiratory minute-volume of a man doing (as assessed) light work and the determination of the percentage of cadmium oxide breathed which was retained in the lungs.

The percentage of retention of cadmium fume inhaled is an unknown quantity in man. Barrett and his co-workers determined this factor in five animal species and they found a 'remarkably constant' 


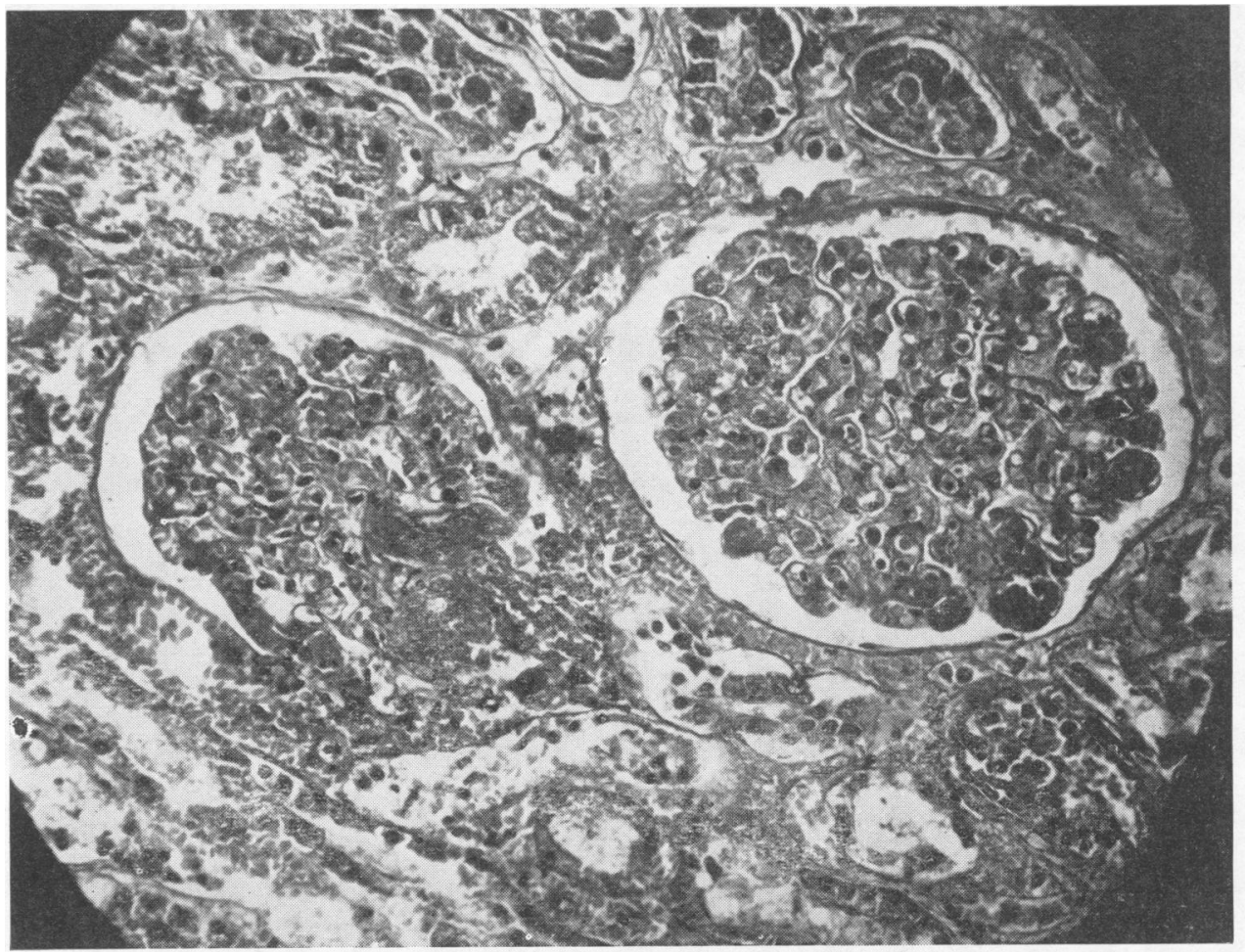

FIG. 4. Glomeruli showing thrombi of vessels and appearances of infarction. $\times 375$.

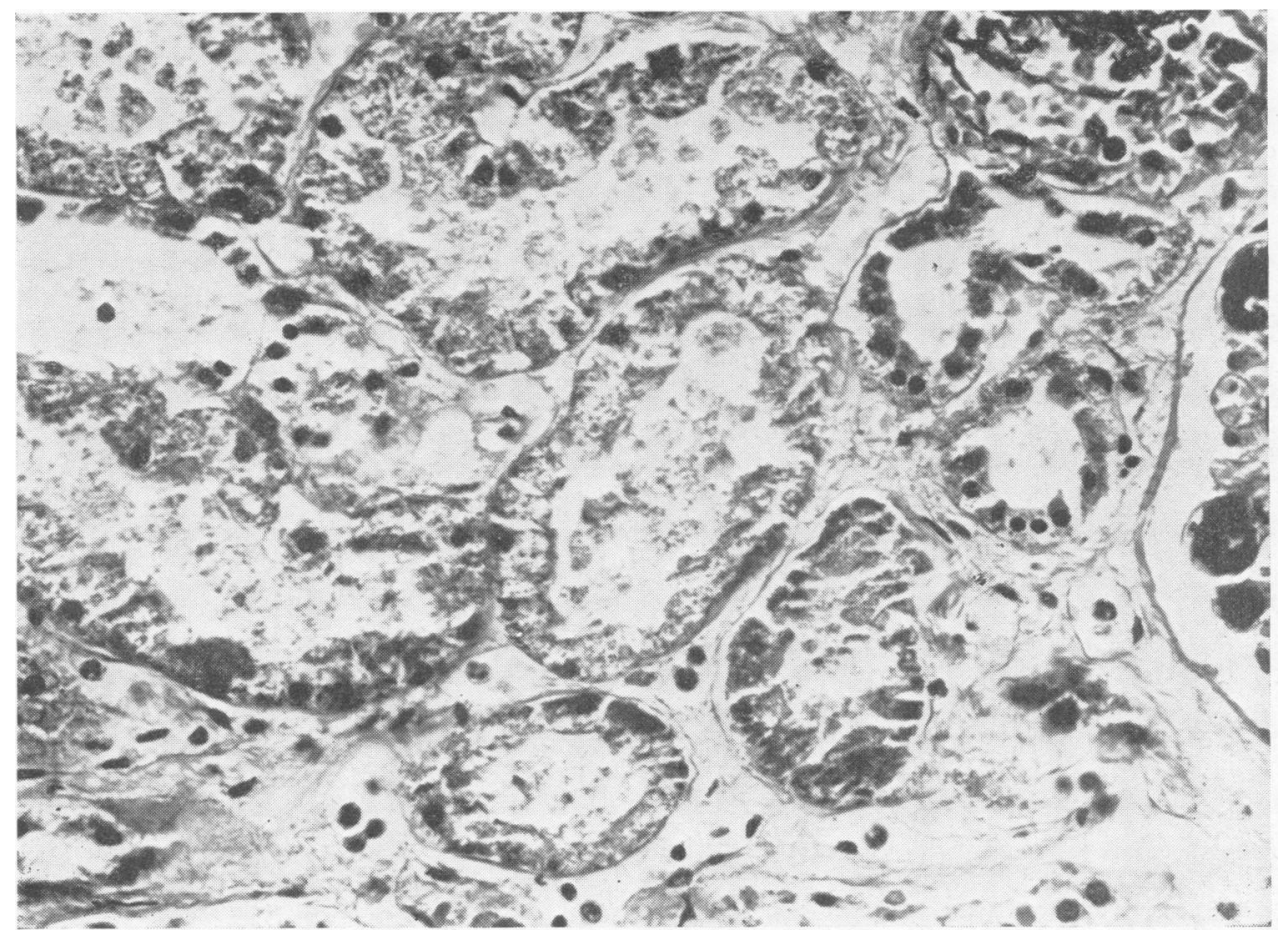

FIG. 5. Renal tubules showing widespread degeneration. $\times 375$. 
figure of $11 \%$ in all five species. For the purpose of their calculation of inhaled dosage, Barrett et al. postulated that $11 \%$ would be applicable to man.

They postulated, too, that the respiratory minutevolume for a man on light work was is litres per minute.

With these factors it was calculated that the lethal dose in the fatal cases was of the order 2,500 minute$\mathrm{mg} . / \mathrm{m} .{ }^{3}$, a reading close to 2,900 minute- $\mathrm{mg} . / \mathrm{m}^{3}{ }^{3}$ of the first study.

The methods used by Barrett and his co-workers were considered with a view to applying them to this series of cases. The work of Barrett and Card could not be repeated in the detail given in their paper as it was impossible to obtain the use of the workplace where this incident occurred. The dimensions of the workplace were determined in detail and, as the confined space held no complication of natural or artificial ventilation, an attempt was made to calculate the quantity of cadmium fume that was put up. This failed as the amount of cadmium that became airborne was diminished by an unknown percentage due to condensation on adjacent cold steel surfaces.

The method of Barrett et al. (1947) in the second study was applied to the post-mortem findings in case I. Their postulate of the II \% retention of cadmium fumes in the lungs was adopted by us, and the respiratory minute-volume of 20 litres per minute was arbitrarily accepted for the men who were doing medium work with periods of relative rest.

The relative factors were:
Weight of lungs
$2,283 \mathrm{~g}$. the lungs specimen)
Cadmium oxide present in $0.25 \mathrm{mg}$./100 g. (wet
Lung retention of cadmium fume inhaled
Respiratory minute volume

$$
\begin{aligned}
& \text { I I \% (Barrett et al.) } \\
& 20 \text { litres/minute } \\
& \text { (estimated). }
\end{aligned}
$$

\section{Calculation}

Weight of cadmium oxide in the lungs $5.7 \mathrm{mg}$.

This is $11 \%$ of the cadmium oxide breathed over five hours. Therefore the weight of cadmium fume breathed in that time was

$\frac{\text { IOO }}{\text { II }} \times 5.7=51.8 \mathrm{mg}$.

The volume breathed in five hours at 20 litres/ minute is $20 \times 5 \times 60=6 \mathrm{~m}^{3}$.

The concentration of airborne fume would therefore be of the order $\frac{5 \mathrm{I} \cdot 8}{6} \mathrm{mg} . / \mathrm{m} .{ }^{3}$, or $8.63 \mathrm{mg} . / \mathrm{m} .{ }^{3}$ or, in terms of minute-mg. $/ \mathrm{m}^{3}, 8.63 \times 300$ minute-mg. $/ \mathrm{m} .{ }^{3}=2,589$ minute-mg. $/ \mathrm{m}^{3}$.

This is a quantity in keeping with the findings of
Barrett et al. (1947) 'namely that 2,500 minute-mg./ $\mathrm{m} .^{3}$ could be a lethal dose'.

The weakness of this calculation is, of course, apparent, and the result submitted has an air of accuracy that is therefore not warranted. The figure for the respiratory minute volume is but a conjecture, but it is suggested that the figure adopted is not grossly in error.

Similarly, there is need for confirmation of the Canadian supposition that an $1 \mathrm{I} \%$ lung retention of cadmium fume in man is a sound postulate. There is indirect support for the Canadian results as the forensic estimation of 2,500 minute-mg. $/ \mathrm{m}^{3}$ compared so closely with the 2,900 minute-mg. $/ \mathrm{m}^{3}$, the result of a careful and detailed animal and atmospheric contamination study.

\section{Discussion}

The symptoms of these workers were in no way different from those of previously reported cases. The latent period before the onset of more severe symptoms allows continued exposure until a substantial dose is received. Few cases in the literature had sufficient symptoms to leave the job in this stage. Also, few cases reported knew of their danger at this stage and did not realize it until much later.

The clinical features of these cases are analysed in Table I. The initial symptoms during exposure were mild and consisted mainly of irritation of the throat and a nasty taste in the mouth. However, after an hour or two the patients developed symptoms suggesting the onset of acute upper respiratory tract infection. Cough, irritation of the throat, general malaise, shivering and sweating with some aches and pains and headaches were the main features.

This stage is similar to the typical 'metal fume fever' from zinc and other metals, often called 'welders' ague'. Zinc fume fever subsides in 12 hours or less, but cadmium cases progress to a prolonged phase of pulmonary reaction with severe, often fatal, pulmonary oedema, which lasts up to seven days, with perhaps superadded bronchopneumonia.

These features were particularly evident in these men. They had by the end of the day developed more severe weakness, dyspnoea, and tightness of the chest, with some wheeze and burning retrosternal pain on coughing. Myalgia, headache, and gastro-intestinal disturbances were also present. Cough was more persistent, in two cases with haemoptysis, and most of the men were restless and breathless at night. These symptoms were less during the day, but all the men managed to go back 
to work within two days of the accident. Among the survivors, symptoms improved by the end of the week, when eventually they entered hospital.

The clinical signs in these cases were very slight on admission, but the chest radiograph showed shadowing suggesting resolving pulmonary oedema and perhaps areas of pulmonary collapse. Lung function tests were normal on admission. There was some elevation of the E.S.R., and a rise in the concentration of serum seromucoid and total protein-bound carbohydrate (Table III). This indicates non-specific cellular damage which could be due to cadmium. Albuminuria of $4 \mathrm{mg}$. $/ 100 \mathrm{ml}$. in a 24-hour specimen was found in one case. Cadmium, however, was found only in very minute traces in the urine of the four men who were tested.

The treatment of the survivors was with rest, oxygen, and antibiotics with early physiotherapy. Chelating agents (e.g., EDTA) were not given as the patients were much improved and these drugs are not without risk of renal damage in this type of case (Friberg, 1957). Cases reported in the literature have shown more striking features. Chest radiographic appearances have persisted for two or three weeks or even longer (Lamy et al., I963). Cardiac infarction has occurred (Reinl, 196I).

A calculation that includes the arbitrary assumptions adopted by Barrett et al. (1947) indicates that these men were exposed to an average atmospheric contamination with cadmium fume of $8.6 \mathrm{mg} . / \mathrm{m.} .^{3}$ over a period of five hours, or, to combine time and quantity, 2,589 min.-mg./m. ${ }^{3}$. This figure coincides closely with the findings of Barrett et al., i.e., $2,500 \mathrm{~min} .-\mathrm{mg} . / \mathrm{m}^{3}$. But, however close this coincidence of the two findings, the use of arbitrary measures of minute-volume respirations, and of the application to man of a 'remarkably constant' average fume retention in animals, militates against a claim of accuracy for these quantities of dosage.

The pathology of this fatal case is similar to that of other reported cases (Bulmer et al., 1938; Paterson, 1947; Christensen and Olsen, 1957) with pulmonary oedema and cuboidal metaplasia of the alveolar lining cells. These pulmonary changes were described in detail by Paterson (1947) in both man and animals. He showed that, in the rat, there were three pathological stages; an initial stage of pulmonary oedema followed by a stage of proliferative interstitial pneumonitis and finally permanent lung damage with perivascular and peribronchial fibrosis. Though the first two of these stages have been described in man, fibrosis has not (as yet). Paterson suggested that there was a possibility that this may develop. In a survivor this might produce permanent symptoms and disability and raise serious problems of compensation.

The case presented here differs in that there is bilateral cortical necrosis of the kidneys, the appearances being similar to those seen in other conditions such as concealed accidental haemorrhage of pregnancy. It seems that this change is probably due to a vascular mechanism associated with the great loss of fluid into the lungs. It could possibly be a direct toxic action similar to that produced by dioxan and diethylene glycol, but, as far as we can determine, the toxic action of cadmium

TABLE III

Serum AND URINe StUdies*

\begin{tabular}{|c|c|c|c|c|c|c|c|c|}
\hline \multirow{3}{*}{$\begin{array}{l}\text { Total } \\
\text { Protein } \\
\text { (Kjeldahl) } \\
\text { (g./roo } \\
\text { ml.) }\end{array}$} & \multirow{3}{*}{$\begin{array}{l}\text { Total } \\
\text { Protein- } \\
\text { bound } \\
\text { Hexose } \\
\text { (mg./10o } \\
\text { ml.) }\end{array}$} & \multirow{3}{*}{$\begin{array}{l}\text { Sero- } \\
\text { mucoid } \\
\text { 'Tyrosine' } \\
(m g . / 100 \\
\text { ml.) }\end{array}$} & \multirow{3}{*}{$\begin{array}{l}\text { Sero- } \\
\text { mucoid- } \\
\text { bound } \\
\text { Hexose } \\
\text { (mg./10o } \\
\text { ml.) }\end{array}$} & \multicolumn{4}{|c|}{ Electrophoresis (g./100 ml.) $\dagger$} & \multirow{3}{*}{ 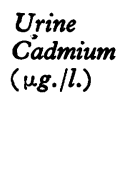 } \\
\hline & & & & Albumin & Globulins & & & \\
\hline & & & & & $\alpha_{2}$ & $\beta$ & $\gamma$ & \\
\hline
\end{tabular}

\begin{tabular}{|c|c|c|c|c|c|c|c|c|c|c|}
\hline \multicolumn{11}{|c|}{ Case 2} \\
\hline $\begin{array}{r}3.10 .63 \\
18.11 .63\end{array}$ & $\begin{array}{l}6 \cdot 8 \\
6 \cdot 4\end{array}$ & $\begin{array}{l}159 \\
102\end{array}$ & $\begin{array}{l}8 \cdot 2 \\
8 \cdot 7\end{array}$ & $\begin{array}{l}20 \\
16\end{array}$ & $\begin{array}{l}3 \cdot 5 \\
3 \cdot 8\end{array}$ & $\begin{array}{l}0.34 \\
0.23\end{array}$ & $\begin{array}{l}0.95 \\
0.56\end{array}$ & $\begin{array}{l}1 \cdot 03 \\
0.87\end{array}$ & $\begin{array}{l}0.93 \\
0.88\end{array}$ & Approx. ro \\
\hline $\begin{array}{r}\text { Case } 3 \\
3.10 .63 \\
18.11 .63\end{array}$ & $\begin{array}{l}6 \cdot 0 \\
7 \cdot 3\end{array}$ & $\begin{array}{l}164 \\
146\end{array}$ & $\begin{array}{l}9 \cdot 1 \\
9 \cdot 3\end{array}$ & $\begin{array}{l}19.6 \\
17.5\end{array}$ & $\begin{array}{l}2 \cdot 9 \\
3 \cdot 8\end{array}$ & $\begin{array}{l}0.34 \\
0.26\end{array}$ & $\begin{array}{l}0.89 \\
0.86\end{array}$ & $\begin{array}{l}0.87 \\
I \cdot 12\end{array}$ & $\begin{array}{l}1 \cdot 07 \\
I \cdot 29\end{array}$ & Approx. Io \\
\hline $\begin{array}{r}\text { Case } 4 \\
3.10 .63 \\
18.11 .63\end{array}$ & $\begin{array}{l}6 \cdot 9 \\
6 \cdot 7\end{array}$ & $\begin{array}{l}152 \\
\text { II4 }\end{array}$ & $\begin{array}{l}8 \cdot 0 \\
8 \cdot 6\end{array}$ & $\begin{array}{l}20 \\
17 \cdot 2\end{array}$ & $\begin{array}{l}3.5 \\
3.7\end{array}$ & $\begin{array}{l}0.30 \\
0.26\end{array}$ & $\begin{array}{l}0.78 \\
0.64\end{array}$ & $\begin{array}{l}I .04 \\
0.98\end{array}$ & $\begin{array}{l}I \cdot 28 \\
I \cdot 15\end{array}$ & Approx. ro \\
\hline $\begin{array}{c}\text { Normal } \\
\text { values }\end{array}$ & $6 \cdot 3-8 \cdot 0$ & $108-140$ & $3 \cdot 0-8 \cdot 0$ & $9 \cdot 0-13.5$ & $3 \cdot 5-4 \cdot 5$ & $0.26-0.40$ & $0.52-0.83$ & $0.71-1 \cdot 17$ & $I \cdot 06-I \cdot 60$ & \\
\hline
\end{tabular}


is specifically upon the tubules and does not involve the glomeruli. It is interesting, however, that bilateral cortical necrosis has been observed in rabbits and dogs following cadmium injection (Severi, I896).

There are not many reports of cadmium analysis of organs in acute poisoning. Barrett and Card (1947) found an average of $1 \cdot 75 \mathrm{mg}$. CdO per 100 g. dried tissue, which is equivalent to $0.35 \mathrm{mg}$. per $100 \mathrm{~g}$. wet tissue. (Barrett suggests dry lung $20 \%$ weight of wet lung.) Our figures compare fairly well with this which is less than has been found in chronic poisoning. (Values of 0.2 to $2.0 \mathrm{mg}$. $/ 100 \mathrm{~g}$. wet lung were quoted by Friberg in 1957.) The finding that liver and kidneys contain a much greater proportion is also observed in chronic poisoning where figures are recorded up to $33 \mathrm{mg}$./100 g. for liver (Bonnell, I955) and Ir. $6 \mathrm{mg}$./100 g. for kidney (Hessling (1952), quoted by Friberg (1957)).

We note above that the long-term effects of a single acute exposure to cadmium fume have not been described, with the exception that Huck (1947) noted no evidence of permanent disability in 64 cases. However, he points out the difficulty in investigating these cases and presumably therefore the difficulty in detecting evidence of permanent disability.

Arrangements have been made for a follow-up study of these cases to establish the extent of any permanent pulmonary or renal damage that they may suffer, and it is hoped to publish these results in due course.

We should like to thank Dr. Grahame Jones for allowing us to study case 5, and Glyn Evans, Esq., H.M. Coroner, for the details of the fatality; Dr. T. A. Lloyd Davies, H.M. Senior Medical Inspector of Factories, for his advice; Dr. J. W. Keyser and Mr. B. T. Stephens for the biochemical studies referred to in Table III; and Mr. Ralph Marshall for the photography. We are indebted to the management of the building operation and to the men for their co-operation.

\section{REFERENCES}

Barrett, H. M., and Card, B. Y. (1947). F. industr. Hyg., 29, 286.

_- Irwin, D. A., and Semmons, E. (1947). Ibid., 29, 279.

Bonnell, J. A. (1955). Brit. F. industr. Med., 12, 181.

, Ross, J. H., and King, E. (1960). Ibid., 17, 69.

Browning, Ethel (1961). Toxicology of Industrial Metals. Butterworths, London.

Bulmer, F. M. R., Rothwell, H. E., and Frankish, E. R. (1938). Canad. publ. Hlth. F., 29, 19.

Christensen, F. C., and Olson, E. C. (1957). Arch. industr. Health, 16, 8.

Drill, V. A. (I954). Pharmacology in Medicine. McGraw-Hill, New York.

Evans, D. M. (1960). Brit. med. F., 1, 173.

Fairhall, L. T. (1946). Brit. F. industr. Med., 3, 207.

Friberg, L. (1950). Acta med. scand. Suppl., 240.

- (1957). Arch. industr. Health, 16, 27.

Gaensler, E. A. (1951). Bull. New Engl. med. Center, 13, 49.

Heully, F., Lamy, P., Pernot, C., and Couillault, S. (1963). Arch. Mal. prof., $24,547$.

Huck, F. F. (1947). Occup. Med., 3, 411 .

Johnstone, R. T. (194I). Occupational Diseases. Saunders, Philadelphia.

Kazantzis, G., Flynn, F. V., Spowage, J. S., and Trott, D. G. (1963). Quart. F. Med., 32, 165 .

Keyser, J. W., and Stephens, B. T. (1962). Clin. Chem., 8, 526.

Lamy, P., Heully, F., Pernot, C., Anthoine, D., Couillaut, S., and Thomas, G. (1963). F. franc. Méd. Chir. thor., 17, 275.

MacFarland, H. N. (1960). Arch. environm. Hlth, 1, 487.

Paterson, J. C. (1947). F. industr. Hyg., 29, 294.

Prodan, L. (1932). F. industr. Hyg., 14, 132.

Reinl, W. (1961). Arch. Toxikol., 19, 152.

Ross, P. (1944) Brit. med. F., 1, 252.

Severi, A. (1896). Arch. Sci. Med., 20, 13.

Shiels, D. O., and Robertson, I. (1946). Brit. F. industr. Med., 3, 213.

Smith, J. P., Smith, J. C., and McCall, A. J. (1960). F. Path. Bact., 80, 287.

Spolyar, L. W., Keppler, J. F., and Porter, H. G. (1944). $\mathcal{F}$. industr. Hyg., 26, 232.

Stephens, G. A. (1920). Ibid., 2, 129.

Sovet (1858). Presse. méd., 10, 69. 